\title{
Gambling on God: A Qualified Defense of Pascal’s Wager
}

\author{
Paul Boaheng \\ Fayetteville State University, Fayetteville, USA
}

\begin{abstract}
The paper critically examines and refutes some of the standard arguments against Pascal's Wager, particularly, the “Many Gods Objection”. The paper argues that Pascal's philosophical and theological opponents proceed far too quickly in dismissing his argument as implausible. Their determined attempts to tear down Pascal's Wager have caused them to miss its power and force. While the Wager may not be sound for today's multi culturally sophisticated audience, the Wager is quite cogent relative to Pascal's time, when theism and agnosticism were the only genuine possibilities. Thus, the paper concludes that Pascal's Wager is less vulnerable than most detractors seem to think.
\end{abstract}

Keywords: Pascal’s Wager, Many-Gods Objection, agnosticism, skepticism

\section{Introduction}

Blaise Pascal, a renowned 17th-century French philosopher, was also a gifted mathematician and a theologian. Pascal's fame as a mathematician rests primarily on his original development of probability theory. His philosophical contributions are found throughout his work, particularly in his Pensées (literally “thoughts"). The Penseés is a collection of philosophical fragments, notes, and essays in which he, among other things, explores the limits of human reason. His Pensées, which were published posthumously, represented an apology for the Christian faith. The portion of Pensées that is the most well-known and most polemical is the Pascal's wager argument.

Pascal, unlike the rationalist philosophers and theologians before him, was skeptical about the efficacy of human reason in demonstrating the existence of God. Consistent with his Jansenist faith, Pascal emphasized the concept of the original sin and human wretchedness, contending that because the human mind had been totally corrupted by sin inherited from Adam and Eve, human reason alone is insufficient to prove God's existence ${ }^{1}$. Consequently, Pascal distrusted natural theology as well as the rationalizations of the philosophers, insisting that philosophical rationalization will inevitably serve as an impediment to the Christian faith.

Pascal's ultimate goal is to convince his skeptical audience that even under the assumption that God's existence is improbable, it always pays to believe in God. He famously utilizes his wager to demonstrate how people have nothing significant to lose but everything to gain when they put their faith in the Christian God. While most philosophers and theologians maintain that Pascal's Wager is the weakest of all arguments for believing in the existence of God, the paper argues that the Pascal's Wager is more compelling than most

Paul Boaheng, Ph.D., Assistant Professor, Department of Government and History/Philosophy, Fayetteville State University. Correspondence concerning this article should be addressed to Paul Boaheng.

1 Pascal seems to be echoing Saint Augustine's claim that the damage sin had done to our rational powers is so great that our mind must be renewed by grace before reason can function correctly. In other words, both Pascal and Augustine are skeptical about the power of reason in proving God's existence. 
detractors think.

\section{Pascal's Wager vs. the Traditional Argument for God's Existence}

Traditional arguments for the existence of God are often categorized into four: Ontological arguments, Cosmological arguments, Teleological arguments, and Moral arguments. Notwithstanding their differences, these traditional, epistemic arguments share one thing in common: They seek to directly proof the existence of God through either reason or experience. For instance, both Aquinas' Cosmological and Teleological arguments are based on experience and observation. Aquinas and other empiricist theologians believe we can justify God's existence by sensory experience. By contrast, some rationalist theologians have justified God's existence independently of experience. For example, Anselm began his ontological proof with the idea of the "the Greatest Conceivable Being”, from which he inferred God's existence. In other words, one of the distinctive features of Anselm's Ontological Argument is that it attempts to prove the existence of God simply from the concept of God.

Pascal distances himself from traditional, epistemic arguments, such as arguments from cosmology, design, ontology, and experience. Pascal, unlike Aquinas and Anselm, argued against the possibility of demonstrative proof of God's existence. For Pascal, God is so completely different from us that there is no way for us to comprehend him. Moreover, he believes that the damage sin had done to human rational powers is so great that human minds are incapable of fathoming God. In short, Pascal relies neither reason nor experience to prove God's existence. Thus, Pascal's Wager, unlike the traditional arguments, does not try to establish that God exists. Rather, it tries to establish a weaker thesis; namely, that it is pragmatically prudent or rational to believe that God exists.

\section{Pascal's Wager: The Historical Context}

To appreciate the depth and significance of Pascal's argument, we need to place his argument in its proper historical context. Pascal lived in a time of great skepticism. Medieval philosophy was virtually extinct, and medieval theology was being frown upon by the new intellectuals of the scientific revolution of the 17th century. The validity of the traditional arguments for the existence of God was no longer taken for granted. Indeed, the notion that God's existence could either be demonstrated via reason was sneered at by the skeptics at Pascal's time. Similarly, the notion of basing one's beliefs in God solely on faith was subjected to public ridicule. In short, neither faith nor reason was compelling enough to motivate the skeptics to believe in God.

Pascal was looking for a third alternative, an alternative that would invoke neither faith nor reason to convince the skeptics to believe in God. That third option was to convince the skeptics as regards why it was pragmatically prudent to believe that God existed. Pascal's Wager claims to be that third option. Thus, Pascal's argument is not meant to show that God exists, rather it is designed to show that it is prudent to believe in God, even if we have no evidence that He exists. Unlike the classic arguments which invoke either reason or evidence to justify God's existence, the Wager carries with it the claim that a person is entitled to believe in God for purely prudential or self-interested reasons. Put differently: Pascal's Wager is not intended to be a philosophical proof; rather, it is intended as a persuasive, pragmatic consideration directed to the skeptics who were also agnostics. ${ }^{2}$ It is worth mentioning that Pascal does not think that the atheist or the believer would be convinced by his Wager. Thus, he primarily directs the Wager to the curious and unconvinced. In a nutshell, his

\footnotetext{
${ }^{2}$ For more on this, see http://www.peterkreeft.com/topics/pascals-wager.htm.
} 
argument was not meant to convert an atheist to wager on God. His wager was specifically meant to convince the skeptics and/or the agnostics that it is rational to believe in God, even if they think it is extremely improbable that God exists.

\section{How the Wager Works}

For Pascal, we have to decide whether or not to believe there is a God. Pascal thinks that by the way, each of us is already leading our lives, we are all already making a bet one way or the other. As he eloquently puts it: "There is no choice, you are already committed.... A coin is being spun which will come down heads or tails. How will you wager? Reason cannot make you choose either, reason cannot prove either wrong” (Pascal, 2002, pp. 134-135). For Pascal, since reason cannot prove that God exists, we need to look at the possible consequences. That is, we have two options: believe in God, or do not believe in God. Now, with each choice, there are possible gains and possible losses.

Table of Possible Consequences

\begin{tabular}{|l|l|l|}
\hline Options & \multicolumn{2}{|c|}{ 4 possible outcomes } \\
\hline Believe in God & God exists and you go to paradise $(+\infty)$ & God doesn't exist, and you waste some time and money $(-10)$ \\
\hline Don't believe in God & God exists and you go to hell $(-\infty)$ & God doesn’t exist, and you have saved money and time $(+10)$ \\
\hline
\end{tabular}

1. If you believe in God, and there is God, the payoff to you is an infinite reward-you go to heaven. The value of going to heaven is infinitely positive. $(+\infty)$

2. If you don't believe there is God, but God in fact exists, the payoff is you suffer an infinite punishment or eternal damnation. $(-\infty)$

3. If you believe in God, but there is no God, you will have wasted your time with religious rituals and observances. This isn't a horrible result, though it should be represented as a modest loss or disutility. (-10)

4. If you don't believe in God, and there is no God: you will not have wasted your time with religious rituals and observances. This isn't a great result, though it should be represented as a modest benefit. $(+10)$

Pascal's conclusion is that regardless of whether God exists, then, theists have it better than atheists; hence belief in God is the most rational belief to have. It follows that even if one thinks the existence of God is extremely improbable, the expected utility of believing is higher than the expected utility of not believing. Because though the existence of God is highly unlikely, there is a huge benefit if one is a theist and God exists, but only an insignificant cost if one is a theist and there is no God. Thus, it makes sense to bet on the existence of God, even if God's existence is very improbable. What Pascal's argument shows is not that God exists, but that it's rational and prudent to believe in God, since this belief promises a higher expected utility than not believing. In sum, even if one thinks all the evidence is against the existence of God, Pascal thinks he can give one a prudential reason for theism, so long as one grants that the existence of God is at least possible.

\section{Some Standard Criticisms of Pascal’s Argument}

\section{The Many Gods Objection}

The wager has been subjected to numerous criticisms. The most common criticism is what is usually referred to as "The Many Gods Objection”. The Many Gods Objection argument goes like this: Suppose one is convinced by Pascal's wager and want to believe in God, given the existence of numerous religions, one wouldn't know what religion to join. In other words, in order to be sure of a payoff, an individual would not 
know which God or gods to believe in to meet the conditions of the wager. Pascal, the detractors' argument continues, assumed the Christian faith, as the only theistic choice, and detractors commonly exploit this simplification to dismiss his entire argument as biased in favor of Pascal's own religion, to wit, Christianity. In short, critics have dismissed Pascal's argument as implausible on the grounds that his argument can be presented in defense of a Jewish God, a Muslim god, a Christian God, a Hindu God, and so on. For example, William James maintains that the wager is indecisive because it would apply, with equal validity, to any religion that offers a promise of infinite rewards (James, 2002, p. 127). The bulk of the paper will be devoted to evaluating the plausibility of the detractors' argument.

While "the Many Gods Objection” has superficial plausibility, I don't think it seriously vitiates the plausibility of Pascal's core argument. It is important to remember that Pascal was primarily directing the Wager to agnostics who were not certain about whether or not the Christian God existed. It is equally important to keep in mind that the Agnostic of Pascal's wager has a noncommittal attitude toward God's existence. Given this fact, it is fair to say that the agnostic is committed to calling out the Atheists for being as equally wrong as the Christians. As far as the agnostics were concerned, there were only two genuine options: theism and atheism. Given this context, Pascal's exclusion of other gods or religions makes perfect sense. Critics are quick to accuse Pascal of committing a fallacy of false alternatives. One commits this fallacy when one assumes that there are only two alternatives to consider when, in fact, there are actually more than two. That said, it should be noted that in cases in which the two options are, in fact, the only two options, there is no fallacy involved. For example, saying that "one is either pregnant or one is not" does not involve a fallacy of false alternative. This is because it rules out other possible options. Similarly, the Agnostic of Pascal's wager was confronted with the choice between two options: either theism or atheism. Succinctly put: The choice was between theism and atheism. The skeptic was not concerned with the existence of other minor deities across the globe. In other words, the skeptics maintained that they would be better "not to wager" at all on the existence of the Christian God. There was nothing in the skeptics' argument that remotely suggested that they were considering wagering for other unknown deities. Given this context, as one commentator puts it "there is no Many Gods Problem because those people whom Pascal addresses never faced with the daunting prospect of deciding in which sort of God they should or should not believe" (Armour Garb, 1999, p. 135).

Even if, for the sake of argument, one concedes that Pascal's Wager cannot decide among religions, one can say that it can at least get us to theism. The idea is that Catholics, Protestants, Jews, Muslims, and other major world religions can all legitimately use decision theory to conclude that it is best to believe in some supreme being. It is not for nothing that the three major religions, to wit, Judaism, Christianity, and Islam, are referred to as Abrahamic religions. These Abrahamic religions claim a direct lineage or origin to Abraham. They are similar in a sense that they are "monotheistic", meaning that they believe in only one God to be worthy of worshipped. Also, and most relevantly, followers of the Abrahamic Religions believe that the righteous will be eternally saved, while the wicked will be eternally doomed.

As long as these major religions are monotheistic and thus theistic, Pascal's Wager can yield generic theism (Armour Garb, 1999, p. 136). Given the commonalities of the Abrahamic Religions, if the skeptic at least wagers on one of the major religions, then he has a chance of "winning". Contrarily, if the skeptic chooses not to wager, then he loses by default. Thus, the skeptic can increase his chances of "winning" by choosing to bet on the Christian God considering He is recognized by the three major religions in the world, and billions of people believe in this God. 
Someone might object to the argument above by contending that just because most people believe in the God of the Bible doesn't necessarily mean it is not rational to wager on other unknown minor deities. Indeed, critics may accuse me of committing the bandwagon fallacy or a fallacy of appeal to popularity. ${ }^{3}$ However, the plausibility of this argument rests on the tacit but dubious assumption that all bandwagon arguments are fallacious. While it is clearly fallacious to accept the approval of the majority as evidence for a claim, I think it is a mistake to conclude that all bandwagon arguments are necessarily bad. For example, consider an American who goes to England and reasons that since everyone there is driving on the left hand side, he should, too. Here there is no fallacy involved in "joining the band" and driving on the left hand side of the road.

Applying this to our argument, one might say that all things being equal, if billions of people believe in the Christian God and only handful of people believe in minor unknown deities, it is only prudent to "join" the majority in betting on the Christian God. While the view of the majority is not infallible, the majority is more likely to be right than the minority. The argument here can be likened to a popular game called "Who Wants to be a Millionaire?". In this game, among other things, a contestant is allowed to use a "lifeline" called "Ask the Audience". The host reads the question and the four possible answers and then the audience will answer the question using an electronic keypad provided by the show with buttons A, B, C, and D. A graph displaying the percentage of people who voted for each answer is shown in the contestant and host's monitor. Assuming $94 \%$ of the audience voted for "A", $3 \%$ voted for B, $2 \%$ voted $\mathrm{C}$, and $1 \%$ voted D. A rational contestant will obviously "wager" on the view of the majority even though the majority may not necessarily be right. Contestants will most likely see which answer has the best chance of being right based on the fact that $94 \%$ of the people are voting for that answer. While there is no guarantee that the $94 \%$ will be right, a prudent contestant will not wager on the $1 \%$ votes. In other words, there are cases where one can legitimately do what most people are doing. Analogously, one might say that the three Abrahamic Religions, which include the Christian God, represent the $94 \%$, while other minor deities represent the $1 \%$. Accordingly, it is rational to wager for God even if there is no guarantee that He exists.

\section{The Professor's God Objection}

Some critics have taken Pascal to task for assuming that God would send believers to heaven and nonbelievers to hell. According to these detractors, this assumption is biased against those who do not share the nature and character of Pascal's God. For example, J. L. Mackie and Richard Dawkins have postulated the possibility of a god that might reward atheists and punish theists. J. L. Mackie speaks for these detractors when he asserts that "there might be a god who looked with more favor on honest doubters or atheists who, in Hume's words, proportioned their belief to the evidence, than on mercenary manipulators of their own understanding” (Mackie, 1982, p. 203). In short, as long as there is a conceivable god who might reward the unbeliever and punish the heretic, Pascal's claim that rationality requires us to wage for the Christina God is biased in favor of the Christian God. Simply put, critics have taken Pascal to task for excluding other assumptions or possibilities. One of the possibilities is what some detractors have referred to as the "Professor's god” (John Mackie, 1982; Martin, 1975; 1990). The "Professor's god”, unlike the Pascal God, is benevolent and will send everyone to heaven except those who are convinced by Pascal's Wager. Further, the Professor's

\footnotetext{
${ }^{3}$ A person falls prey to this fallacy if he or she accepts a claim as being true simply because most other people approve of the claim.
} 
god will specifically reward atheists and punish those who adopt theism. So long as the professor's god is an epistemic possibility, according to critics, it ought to be entered into the Pascalian decision-theoretic analysis. Thus, Pascal's argument has been dismissed as fallacious because it question-beggingly rules out the "Professor's god as one of the viable options to be rationally wagered on" (Saka, 2001, p. 334).

While this "Professor's god" hypothesis is philosophically interesting, it is irrelevant as far as Pascal's Wager is concerned. To begin with, expecting a god who is kind to unbelievers and cruel to believers is farfetched; no one has really believed in such a god. Since Pascal's Wager is a pragmatic argument, it is a mistake to invoke a bizarre god to refute his argument. Since no one currently believes in the existence of the professor's god, coupled with the fact that the Agnostic of Pascal's wager did not believe in such an exotic god, Pascal is justified in omitting the "professor's god" from his cost/benefit analyses. Indeed, any god not known to Pascal's audience cannot be counted, in Jamesian phraseology, as a genuine option. Pascal and his skeptical audience were not interested in a possible god such as "Professor's god" who will reward non-believers and punish believers. Thus, it can plausibly be concluded that when Pascal excluded other possibilities, he was giving a fair picture of the choices actually confronting his agnostic audience or interlocutors (Franklin, 1998; Rescher, 1995).

\section{A Godless Heaven: The Atheist's Wager}

In response to Pascal's Wager, some detractors have contended that atheists might still enjoy a blissful afterlife in some paradise without betting on the Christian God. Thus, the atheist might win the bet. Some atheists have referred to this as The Atheist's Wager ${ }^{4}$, as opposed to Pascal's Wager. However, one might contend that while "a godless but blissful afterlife" is an epistemic possibility, most, if not all, Atheists cannot consistently subscribe to this line of reasoning. This is so because most atheists are naturalists, who deny the existence of life after death. For unadulterated naturalists, nothing exists outside time and space. Thus, they believe in here and now. In short, belief in afterlife seems inherently incongruous with atheism. Thus, consistency seems to bar "naturalist" atheists from utilizing the possibility of no-god afterlife argument to reject Pascal's argument.

It might be replied that if there were an afterlife that doesn't require a god, then being an atheist does not necessarily rule out belief in after life. In other words, it is possible for atheists to believe in afterlife if that afterlife is associated with any god or gods. However, if atheists took refuge in this line of reasoning, they would have a hard time justifying their association of theism with irrationality. For most Atheists agree with evidentialists that because believers do not have evidence that God exists, it is irrational to believe in God. Indeed, some atheists' scholars have dismissed Pascal's wager as irrational on the grounds that Pascal asked his audience to wager in an evidential vacuum. ${ }^{5}$ Ironically, the validity of the atheist's argument inadvertently vitiates their own criticism of Pascal's wager. With delicious argument, one could use the atheists' argument against them by contending that since there is no evidence that there is life after death, it would be irrational to believe in an afterlife, the same as it would be irrational to believe in a god. In other words, atheists cannot, without inconsistency and irrationality, sustain their trenchant criticism of Pascal while believing in after life.

\footnotetext{
${ }^{4}$ The Atheist's Wager was first formulated by Michael Martin in his Atheism: A Philosophical Justification (1990). As the name of his book suggests, he presents an atheistic response to Pascal's Wager regarding the existence of God.

${ }^{5}$ For example, in his "The Ethics of Belief”, William Clifford famously argues that believing in God without sufficient evidence is always irrational and thus wrong. As he colorfully puts it: "It is wrong always, everywhere, and for any one, to believe anything upon insufficient evidence” (2002, p. 125).
} 
In a nutshell, the argument that one can be an atheist and also belief in afterlife is self-incriminating, if not self-destructive.

In response, a naturalist atheist might argue that one does not have to believe in afterlife in order to enjoy a blissful life. If one believes there is no afterlife, but one behaves ethically towards one's fellow human being, the argument continues, one will live an eternally joyous life. In effect, belief in no afterlife can lead a moral person to live in heaven on earth infinitely.

While this argument is philosophically illuminating, in my view, it is conceptually wrong to assume that there is any infinite reward if there is no afterlife. It is indisputable that the mortal life is finite and if there is nothing after death then that inevitably eliminates all rewards. Therefore, only temporal, finite gains would be available. Thus, it is impossible for an atheist to be rewarded infinitely here on earth. At best the reward will be finite. All the gains that the Atheist can talk about can only be referred to gains in this living but ephemeral life. But the gains the Wager referred to are gains in afterlife, which Pascal believes are far superior. It makes no sense to talk about eternal life on earth, but it is sensible to talk about eternal life in heaven. Thus, if the atheist "wins", he receives a finite reward, while if the theist wins, he receives an infinite reward. Thus, Pascal is right in insisting that it's rational and prudent to believe in God, since this belief promises a higher expected utility than not believing.

\section{Self-interest and Christianity}

Although Pascal's wager is an apologetic for belief in Christianity, some of the harshest criticisms levelled against it come from theist circles. Pascal's Wager, as we have seen, is an attempt to justify belief in God not with an appeal to evidence for God's existence, but rather with an appeal to self-interest: It is in our interests to believe in the God of Christianity.

Pascal's "self-interested" argument has generated criticisms and consternation among some Christian detractors, mainly on the grounds that self-interest is not a good reason to believe in God. Critics are quick to point out that Pascal's Wager reduces religion to a self-interested game, rather than a joyous appreciation of God's intrinsic goodness. William James, for example, finds the tacit appeal to self-interest in Pascal's wager to be an embarrassment to Christians in general. In his "The Will to Believe" (2002), he offers a sharp critical assessment of the Wager and finds Pascal's basic argument to be insincere. For James, simply deciding to believe in God because it is in one's best interest to do so is rather vacuous and selfish. "Not only is it lacking a good motive, it would not be real faith” (William James, 2002, p. 126).

While most Christians vehemently disparage the notion that any moral decision might be motivated by self-interest-eternal reward to be gained or punishment to be avoided, I think there is no shame or "unchristian" in choosing an option that results in promotion of one's interest. Indeed, as Thomas Hobbes reminds us, the preservation of one's life is a natural end or objective toward which all activity is directed. Hobbes rightly argues that Christians have self-interested motivation for obeying divine commands. Christians believe in God because if they disobey him, He has the power to crush them at will. Thus, for Hobbes, as for Pascal, it is prudent to obey God. Thus, when Pascal insisted that it is prudent for any rational theists to submit to the will of God, he was being realistic as regards human nature. Human beings are, by nature, self-interested; therefore, only self-interest can motivate the theist to believe in God.

Theists who are embarrassed by the appeal to self-interest in Pascal's Wager seem to conflate selfish acts with self-interested acts. Selfish acts advance one’s own interests regardless of how others are affected. Thus, a 
selfish person lacks consideration for others, and/or is concerned chiefly with his/her own personal profit or pleasure. Self-interested acts, on the other hand, promote one's interests but not necessarily to the detriment of others. Indeed, self-interest would motivate us to take into consideration the interest of others. This implies that one could be self-interested yet not morally bereft of compassion and generosity. Human beings, including Christians, care about others because doing so affects their own happiness. Indeed, to promote one's own interests, one may actually find oneself helping others. In short, Christians help themselves by helping others. Thus, self-interest, so construed, is benign to the welfare of others. This being the case, there is nothing embarrassing in associating Christianity with self-interest. Pascal, like modern philosophers such as Hobbes, bases his wager on what humans are by nature. Rather than providing Christians with an ideal and a quixotic standard to which they should aspire, Pascal deals with Christians as they are: rational, self-interested and calculating.

\section{Conclusion}

It has been argued that Pascal's Wager is not intended to be a philosophical proof; rather, it is intended as a persuasive, pragmatic consideration directed to the skeptics who were also agnostics. Against the detractors, the paper has maintained that since the Agnostic of Pascal's wager was not concerned with the existence of other minor deities across the globe, the "Many Gods Objection" does not diminish the plausibility of Pascal's argument. Furthermore, it has been contended that since Pascal's Wager is a pragmatic argument, it is a mistake to invoke an exotic god to refute his argument. Since no one believed and currently believes in the existence of the professor's god, Pascal is justified in omitting such an esoteric god from his cost/benefit analyses. As we saw, Pascal and his skeptical audience were not interested in a fictitious god who will reward non-believers and punish believers.

In opposition to theist detractors who find the appeal to self-interest in Pascal's wager to be an embarrassment to Christians, I distinguished selfish acts from self-interested acts. Self-interested acts, unlike selfish acts, would motivate believers to take into consideration the interest of others. Consequently, the appeal to self-interest in Pascal's wager should not embarrass Christians who otherwise might find his argument to be compelling. Pascal's Wager was merely a motivation to help the skeptics open their minds to believing. Pascal was trying to provide skeptics incentive to belief in God, and what could be a better incentive than self-interest!

\section{References}

Armour-Garb, B. (1999). Betting on God. Religious Studies, 35, 119-138.

Clifford, W. K. (2002). The ethics of belief. In J. Feinberg and R. Shafer-Landau (Eds.), Reason and responsibility (pp. 121-125). Belmont, CA: Wadsworth Press.

Franklin, J. (1998). Two caricatures: I: Pascal’s Wager. International Journal of Philosophy and Religion, 44, 115-119.

James, W. (2002). The will to believe. In J. Feinberg and R. Shafer-Landau (Eds.), Reason and responsibility (pp. 125-133). Belmont, CA: Wadsworth Press.

Jordan, J. (1991). The Many-Gods objection and Pascal’s Wager. International Philosophical Quarterly, 31, 309-317.

Jordan, J. (1994b). The Many-Gods objection. In Jordan (Ed.), Gambling on God (pp. 101-114). Lanham MD: Rowman \& Littlefield.

Mackie, J. L. (1982). The miracle of theism. Oxford: Oxford University Press.

Martin, M. (1990). Atheism: A philosophical justification. Philadelphia: Temple University Press.

Morris, T. (1994). Wagering and the evidence. In Jordan (Ed.), Gambling on God (pp. 47-60). Lanham MD: Rowman \& Littlefield.

Blaise, P. (1966). Pensées. (A. J. Krailsheimer, Trans.). Baltimore and Harmondsworth: Penguin Books. 
Blaise, P. (2002). The Wager. In J. Feinberg and R. Shafer-Landau (Eds.), Reason and responsibility (pp. 134-137). Belmont, CA: Wadsworth Press.

Quinn, P. (1994). Moral objections to Pascalian Wagering. In Jordan (Ed.), Gambling on God (pp. 61-82). Retrieved December 6, 2015, from http://www.peterkreeft.com/topics/pascals-wager.htm

Saka, P. (2001). Pascal's Wager and the many Gods objection. Religious Studies, 37(3), 321-341. 